\title{
Litteratursamtalens danningspotensial
}

\author{
Gro Ulland*, \\ Høgskolen $i$ Bergen, avdeling for larerutdanning, Bergen, Norge
}

\begin{abstract}
Sammendrag
I denne artikkelen brukes litteratursamtalen som eksempel når jeg undersøker hvordan forholdet mellom lærer, elev og tekst kan være betydningsskapende og dermed ha potensial for danning hos elevene. Både Gert Biesta og Wolfgang Klafki tydeliggjør lærerens ansvar og rolle i arbeidet med å tilrettelegge for elevenes muligheter til å realisere dette potensialet. Artikkelen viser særlig hvordan Biestas begreper om «tillit», «ubehag» og «ansvar» kan beskrive dynamikken mellom lærer og elev i en læringssituasjon, men også hvordan læreren må identifisere substansen i et innhold slik at dette i neste omgang kan bety noe for eleven. Den litterære samtalen som fungerer som eksempel i artikkelen, er en samtale mellom en lærer og fire elever, knyttet til den skjønnlitterære barneboken Brune (2013). Elevene går på 5. trinn ved en skole i Bergen. Undersøkelsen viser at den litterære teksten og samtalen om den, øver opp elevenes etiske og estetiske refleksjonsevner fordi teksten utfordrer elevene i forhold til deres etablerte forestillinger, mens selve samtalen inviterer elevene til å respondere med egne meninger og følgelig gir dem en stemme i fellesskapet.
\end{abstract}

Nøkkelord: Danning; litteratursamtalen; mening; laringssituasjon

\begin{abstract}
In this article, I use the literary conversation as example while I investigate how the relationship between teacher, student and text can be significant and thus have a potential for the formation of students. Both Gert Biesta and Wolfgang Klafki clarifies the teacher's responsibility and role in facilitating students' opportunities to bring out this potential. The article shows in particular how Biestas concepts of 'trust', 'violence' and 'responsibility' can describe the dynamic relation between teacher and pupils in a learning situation. It also shows how the teacher must identify the substance in a content in order to present this in a way that gives meaning for the learner. The literary conversation that serves as example in the article, is a conversation among a teacher and four pupils about the fictional children's book Brune (2013). The pupils are all 10 years old, and live in Bergen, Norway. My research shows that the literary text and the conversation following it strengthen the pupils' ability to reflect ethically and esthetically because the book challenges their established ideas, while the actual conversation invites them to respond with their own voices and thus allows them to act as independent participants in the group.
\end{abstract}

Keywords: Education; literature conversation; formation; learning situation

Received: January 2016; Accepted: September 2016; Published: December 2016

^Korrespondanse: Gro Ulland, Høgskolen i Bergen, avdeling for lærerutdanning, postboks 7030, 5020 BERGEN. E-post: gul@hib.no 


\section{Gro Ulland}

\section{Innledende perspektiver på danning}

I Kunnskapsløftet, LK06, omtales norskfaget som et danningsfag. I det skal elevene lære å lese og forstå mange forskjellige typer tekster fra ulike tider. Det er underforstått at arbeidet med litteratur i norskfaget har et stort danningspotensial. Her får elevene blant annet innsikt i og oversikt over et kulturelt felt (litteraturen). De leser litteratur på måter som øker den generelle forståelsesevnen deres, som bidrar til identitetsutvikling og lærer dem noe om seg selv, historien og verden. Samtidig læres de opp til å lese et stort antall aktuelle tekster fra samtiden med et kritisk blikk. For å realisere danningspotensialet i litteraturundervisningen er det viktig at læreren legger til rette for at elevene får et aktivt forhold til tekstene de skal lese. Litteratursamtalen er en av flere mulige metoder som nettopp bidrar til en ønsket selvutviklende deltakelse fra elevenes side - et møte med litteraturen der hver enkelt deltaker må gjøre seg opp en mening om hva det er de forstår av det de har lest, for så å bryne egne oppfatninger mot andres.

I denne artikkelen vil jeg blant annet i lys av danningsteoretiske tekster av Klafki (2000) og Biesta (2006) undersøke elevenes møte med litteratur og litteratursamtalen slik dette er tilrettelagt av læreren. Skjønt en ikke kan måle eller vite med sikkerhet hva som kommer ut av et slikt møte, er den overordnede målsettingen med artikkelen å si noe om litteraturen og litteratursamtalens betydning for elevene, og følgelig potensialet samtalen kan ha for danning. En didaktisk praksis som gir mening for elevene, henger uløselig sammen med læreren som tilrettelegger for denne praksisen. Ved å reflektere rundt lærerens tilrettelegging av litteratursamtalen og elevenes respons, ønsker jeg derfor å synliggjøre nettopp hvordan undervisningen kan bidra til elevenes utvikling. I tillegg til Biesta og Klafki, vil jeg dra veksler på teori av Hopmann (2010), Willbergh (2010) og Aase (2005) når det kommer til beskrivelsen av dette møtet.

Stefan Hopmann beskriver danning som «prosessen med å utvikle individualitet gjennom læring» (2010, s. 28). Dette må ikke forstås slik at en skal overføre mest mulig kunnskap fra samfunnet til individet, men at det som blir gjort eller lært, fører til en utvikling i den enkeltes individualitet (Hopmann, 2010). Det er ifølge Hopmann ikke innholdet alene eller undervisningen alene som kan åpne for danning, men det eksakte møtet mellom eleven og innholdet kan for den enkelte elev føre til tanker og handlinger som varer ved etter at møtet er slutt, og spille inn på hvordan eleven videre forstår seg selv, andre eller verden i sin helhet. Laila Aase forstår danning på en lignende måte når hun skriver at møtet mellom en bestemt elev og et bestemt innhold kan få eleven til å se sammenhenger han ikke tidligere har sett (Aase, 2005b). Det vil si at danning kan fremtre idet eleven møter innholdet i undervisningen og der noe blir igjen i ham, der det gjør noe med ham. At danning skal være et overordnet mål for undervisningen, kan forstås som at den skal forberede elevene til å kunne fungere som autonome individer i framtiden, for eksempel i arbeids- og samfunnslivet. Derfor vil alt som gir dem kunnskaper, former personligheten deres, og gjør dem i stand til å delta og samhandle i offentlige rom og sosiale sammenhenger, kunne bidra til danning. Danningen er individuell, og det er ikke mulig å måle om danning foregår 
eller er satt i gang som en prosess rett etter en undervisningsøkt. Derfor snakker vi heller om at undervisningen har et danningspotensial og mener at elevene kan ha fått øvd opp ferdigheter eller skaffet seg kunnskaper som ligger latente og som kan aktiveres seinere i form av (kvalifisert) tankevirksomhet eller velfunderte handlinger.

Ifølge Hopmann er det betydningen en elev opplever i møtet med læreren og et undervisningsinnhold som har danningspotensial. Denne betydningen strekker seg lenger enn selve innholdet, og den muliggjøres når innholdet spilles ut i et klasserom, basert på lærerens valg og forberedelser. Imidlertid minner Hopmann om at

selve møtet og dets utfall ikke er innebygget i innholdet eller gitt av undervisningen, men bare fremtrer i den aktuelle situasjonen, der og da hvor møtet mellom en bestemt elev og et bestemt innhold finner sted. Danning er dermed det som blir igjen utover dette situerte møtet (2010, s. 30).

I et slikt møte er det helt individuelt om danning vil forkomme, og ulike elever vil ha ulike muligheter til å knytte ulik betydning til innholdet. Innholdet kan ha både muligheter og begrensninger, og to elever trenger ikke ta ut den samme betydningen fra den samme situasjonen. En litterær tekst kan for eksempel åpne opp for å lære om egne tanker, menneskelige forhold og nyanser av følelsesliv. Da representerer den litterære teksten undervisningens innhold, og skal føre til at elevene forstår noe nytt. Dette siste er ikke (nødvendigvis) iboende i faginnholdet, men møtet med faginnholdet kan åpne opp for å utvikle tanker, meninger og kunnskaper.

Det læreren kan gjøre er å tilrettelegge undervisningen på en måte som åpner opp for elevens individuelle vekst (Hopmann, 2010). Det gjør han ved å konstruere rammer som er meningsfulle og muliggiør danning for elevenes vedkommende. Slike rammer innbefatter å velge ut og formidle et innhold som engasjerer og som oppfattes som viktig for elevene. Denne utvelgelsesprosessen beskrives av Klafki som «the interplay between experience and reflection» (2000, s. 143), og den må hver gang giøres med konkrete elever og en konkret situasjon i tankene. Lærerens utvelgelse og tolkningsarbeid kan karakteriseres som en kvalifisert gjetting på hva som kan gi mening for elevene (Willbergh, 2010). I denne prosessen kan læreren støtte seg på tidligere erfaringer som bidrar til at han til en viss grad kan forvente eller forutse en bestemt reaksjon i møtet mellom et bestemt innhold og bestemte elever (Hopmann, 2010). Dette kan ses på som lærerens bidrag til elevenes danning.

\section{Litteratursamtalen}

En litterær samtale defineres som en «klassesamtale som uttrykker leseerfaringer og som har som formål å undersøke litterære tekster med utgangspunkt i desse erfaringane» (Aase, 2005b, s. 106). Som sjanger er den litterære samtalen både institusjonell og iscenesatt. Institusjonell fordi den foregår på skolen og i klasserommet, og iscenesatt fordi den er iscenesatt av læreren. Litteratursamtalen er en åpen arena der det forhandles mellom og kjøpslås om ulike fortolkningsforslag. Den er sosial, dialogisk og utprøvende. Etienne Wenger (1998) skriver at litteratursamtalen er en forhandling om mening, og at denne meningen blir konstruert $\mathrm{i}$ 


\section{Gro Ulland}

fellesskap. For elevene er litteratursamtalen en språkliggjøring av egen tekstforståelse. Det særegne er at deltakerne snakker om teksten, og så kan de velge å vise seg frem med egne meninger i tilknytning til denne (Aase, 2005b). Elevene må innta roller og handle spontant på bakgrunn av det de har lest og utfra hvordan samtalen utvikler seg. Litteratursamtalen er derfor både læring av fag og opplæring i medborgerlig deltakelse. Samtidig kan litteratursamtalen utvikle elevenes tekstforståelse ved at denne blir utfordret i møte med de andre elevenes tolkninger. Det at elevgrupper og tekster til enhver tid er ulike, bidrar til at hver enkelt litteratursamtale er unik.

Den litterære samtalen som fungerer som eksempel i denne artikkelen, er en samtale mellom lærer og fire elever på 5. trinn, om den skjønnlitterære boken Brune (2013). Dette er elevenes første møte med boken. Kort presentert er Brune en illustrert barnebok for aldersgruppen 9-12 år. Den handler om Rune som akkurat har mistet bestefaren sin, og som opplever å få lekehytta si ødelagt av tre eldre gutter. Som en hevnaksjon, eller bearbeiding, kler Rune seg ut som Brune om natten, og tar hevn ved å male en av bøllenes sykkel brun. På denne nattlige vandringen møter han også den døde bestefaren, som låner ham øre slik at Rune kan få spørre og fortelle om det han har på hjertet. Tematikk som vennskap, mot og hverdagsmagi gjør boka aktuell for målgruppen ved at den berører det de selv går og tenker på i sin egen hverdag. Samtidig er hovedpersonen i en overgangsfase der han må erkjenne at bestefaren er død og der fraværende voksenpersoner gjør at Brune må ordne opp i problemene sine på egen hånd. Slik sett er det gode muligheter for identifikasjon for lesere som også befinner seg $\mathrm{i}$ en brytningstid, og boka åpner for en diskusjon om krenkelsesmestring og om grensene mellom fantasi og virkelighet. Teksten er flertydig, med innslag av fantastiske elementer. Det at den døde bestefaren trer inn i fiksjonsuniverset, er en utfordrende episk struktur som krever at elevene har sjangerkunnskap nok til å gjenkjenne fantastiske elementer i teksten.

Samtalen er hentet fra et forskningsprosjekt som utforsker tekstsamtalen som danningsområde, og da særlig hvordan unge lesere er kreative i sin måte å forstå tekst på. ${ }^{1}$ Samtalene er tatt opp på. bånd, og transkriberte i ettertid. Elevenes navn er fiktive, og prosjektet er godkjent av Norsk samfunnsvitenskapelig datatjeneste.

Jeg vil i det videre se på hva det er i forholdet mellom lærer, elev, tekst og den litterære samtalen, som kan føre til betydning og dermed ha potensial for danning hos elevene. Både Biesta (2006) og Klafki (2000) tydeliggjør lærerens ansvar og rolle $\mathrm{i}$ arbeidet med å tilrettelegge for elevenes muligheter til å hente ut denne betydningen. Biesta tar for seg hva det vil si å ha et utdanningsansvar og hvordan relasjonen mellom lærer og elev arter seg i en læringssituasjon, mens Klafki fremhever hvordan læreren må identifisere substansen i et innhold slik at dette i neste omgang kan internaliseres av eleven og bety noe for henne. Selv om de begge snakker om generelle læringssituasjoner, kan både begrepsbruken og betraktningene deres være anvendbare i tilknytning til den litterære samtalen. Jeg vil særlig ta i bruk Biestas begreper om «tillit» (trust), «ubehag» (violence) og «ansvar» (responsibility) i denne sammenhengen, men

\footnotetext{
${ }^{1}$ Prosjektnavn: Barns lesekunst/Lesesamtaler som grunnlag for metakognitiv bevissthet.
} 
først vil jeg se på hvordan Wolfgang Klafki (2000) beskriver det å identifisere betydningsinnholdet $\mathrm{i}$ et undervisningsinnhold.

\section{Klafki, forberedelse og innhold}

Klafki beskriver lærerens kjerneoppgave som å velge ut et innhold og å utforske hvilke aspekter av innholdet som kan bidra til danning (2000). Der Hopmann (2010) og Willbergh (2010) presiserer at det er det eksakte møtet mellom eleven og innholdet som kan åpne for betydning og danning, og at innholdet alene ikke har denne funksjonen, støtter Klafki seg på Willmann når han derimot peker på at et innhold kan ha en iboende substans som fremstår som «wise, something vital, something invisible but objective which needs to be grasped if the matter is to be mastered» (Willmann, gjengitt etter Klafki, 2000, s. 147). En slik forståelse utdyper hvordan innholdet kan skape betydning for den enkelte elev, som noe som hun kan gripe tak i, forstå, og gjøre til sitt eget. Selv om denne betydningen er en abstrakt enhet, vil elevene kunne gjenkjenne den som noe de er i besittelse av. Klafki utdyper «possess»-begrepet ved å referere til Weniger: [it] ... can be grasped and possessed by a person and yet remains unspent and independent. But for the person «educated» by this entity (...), it has become his property; he has experienced the values concealed therein as educational values (...) and possesses them. (Weniger, gjengitt etter Klafki, 2000, s. 149.) Vi skal se nærmere på hvordan Klafki mener læreren kan sette elevene $\mathrm{i}$ stand til å gripe betydningen $\mathrm{i}$ et innhold.

Idet læreren starter forberedelsene sine, er hans første avgjørelse, ifølge Klafki, hva det er som skal læres. Når det gjelder å velge et innhold, må læreren hente støtte i læreplanens rammer, men han er likevel fri til å gjøre mange av valgene selv. Klafki argumenterer for at undervisningens innhold er skapt av samfunnet vi lever i. Det skyldes at autoriteter som kirken, rettssystemet, forskning, kunst, handel og samfunnsstrukturer utgjør sivilisasjonen som sammen skal bestemme og gjenspeiles i utdanningsinnholdet (Klafki, 2000). John Dewey omtaler det samme innholdet som «certain social aims, meanings, values incarnated in the matured experience of the adult» (1990/1902, s. 4). Også dette understreker at innholdet gjenspeiler den kulturen og de verdiene tidligere generasjoner har sett på som viktige. Med tanke på tekstvalg i tilknytning til litteratursamtalen, må læreren finne frem til tekster han tror kan være kvalitativt givende for den målgruppen han underviser. Norske læreplaner bestemmer ikke hvilke tekster som skal leses, men hvis vi skal forfølge Klafkis resonnement, kan faktorer som forlag, lærebokforfattere, media, bibliotek og økonomi indirekte være avgjørende for hvilke tekster som leses i klasserommet. I Kunnskapsløftets omtale av norskfagets formål kan vi lese at

gjennom aktiv bruk av det norske språket innlemmes barn og unge i kultur og samfunnsliv, og rustes til deltakelse i arbeidsliv og demokratiske prosesser. Norskfaget åpner en arena der de får anledning til å finne sine egne stemmer, ytre seg, bli hørt og få svar (Utdanningsforbundet, 2013). 


\section{Gro Ulland}

Det betyr at tekstene som velges skal virke utviklende på elevene, samtidig som de skal læres opp til å snakke og skrive om det de har lest.

Etter valg av innhold, er det neste steget i forberedelsene å forstå innholdet. Det vil si å avdekke hva det er i innholdet som potensielt kan være av betydning for eleven. Dette punktet hos Klafki sammenfaller med hvordan læreren best kan forberede en tekstlesing med elevene (Hennig, 2010). Det vil si at læreren finner frem til det som kan gi grobunn for undring, samtale og videre tankegang. Det er her læreren ifølge Klafki må vurdere innholdet både $\mathrm{i}$ forhold til de lekmenn elevene skal bli og $\mathrm{i}$ forhold til de barna de er («the lay-person and the child»). Som erfaren leser og teksttolker vil læreren i vårt tilfelle forstå at teksten er en realistisk barnefortelling med fantastiske elementer, han forstår at forfatteren har brukt magiske innslag idet Brune møter bestefaren, og han forstår at forfatteren på den måten tematiserer hvordan barn takler sorg gjennom fantasi og hvordan de voksne er fraværende i sorgprosessen. Hvorvidt den gamle mannen Brune møter om natten virkelig er den avdøde bestefaren, vil være et spørsmål som kan virke uforståelig og skape undring. Nettopp derfor kan tekstutdraget ha potensial til å utvikle elevenes estetiske sans, fordi de leser noe som er krevende å forstå eller godta. Læreren vil også se at akkurat denne litterære teksten åpner opp for undervisning om emner som magiske innganger og fortellingen som sjanger. Her må læreren finner en nerve i innholdet som han ønsker å videreformidle slik at elevene kan få en leseopplevelse som kan vare ved i dem etter endt lesing. Klafki sier læreren må representere og personifisere innholdet for å kunne formidle det til eleven (2000).

Idet læreren tar den unge elevens posisjon, vil han på den andre side forstå at elever som har mistet en besteforelder lett kan identifisere seg med hovedpersonen. Han kan også ta inn over seg at det er vanskelig å forstå hvordan en som egentlig er

død kan snakke og vise seg for Brune. Kanskje noen elever til og med vil avvise teksten fordi den ikke stemmer overens med egen virkelighetsoppfatning. Dette har å gjøre med den unges forståelseshorisont. Som en del av forberedelsene må læreren forutse den unge elevens kapasitet, mulige spørsmål, interesser og holdninger og se dette i forhold til elevens danningspotensial. Han må også ta stilling til hvilken generell betydning innholdet kan ha og hva det kan ha å si for elevgruppen ved et senere tidspunkt. I dette ligger å gripe det generelle i det spesielle, læreren må gjenkjenne hva det er $\mathrm{i}$ et spesielt innhold som kan peke utover og representere problemstillinger og verdier som kan ha betydning for elevenes liv.

\section{Laring som respons}

Gert Biesta mener at vi må se på læring som respons framfor å tenke på læring som noe eleven tar i besittelse. Læring blir da ikke noe en kan eie, men en indre reaksjon på undervisningsinnholdet som blir presentert en:

This not only means that there must be something to respond to - a curriculum, for example, but not a curriculum as the content that needs to be acquired but as the practice that allows for particular responses (2006, s. 28). 
Det er selve reaksjonen, ens egen respons, som innebærer læring, og en slik reaksjon vil ofte bli fremprovosert i læringssituasjoner der en møter noe en ikke kjente til fra før og kanskje også noe som ikke stemmer med det en tidligere har antatt. På denne måten blir det umulig å snakke om læring utelukkende som tilegnelse av kunnskap eller ferdigheter, men også som en individuell reaksjon på læringsinnholdet. Biesta giør det klart at en nok kan definere en læringsprosess både som å tilegne seg et læringsinnhold og som å respondere på et læringsinnhold, men at sistnevnte vil være den mest karakteristiske definisjonen på læring. Han beskriver det slik: «While learning as acquisition is about getting more and more, learning as responding is about showing who you are and where you stand» (2006, s. 27). Gjennom respons får elevene en egen stemme. Meningsfulle rammer som muliggiør danning vil være situasjoner der læreren gir eleven muligheten til å bruke sin egen stemme.

Et slikt syn på læring fordrer at læreren har en habitus som viser interesse for elevens tanker og følelser og inviterer elevene til å respondere med sin egen stemme. Det handler om situasjonen, men det handler like mye om det læringsklimaet som etableres i klasserommet. I en litteratursamtale vil det være essensielt om læreren har etablert et klima der en er vant til å snakke om tekst. Det er også avgjørende å ha et språk for å snakke om teksten. Læreren må i opplæringen ha presentert faglige begrep som for eksempel fortellestemme, motiv og karakterer for at eleven så presist som mulig kan uttrykke sin egen mening og respondere på teksten. Ved å forberede elevene på denne måten, vil en ha tilrettelagt for et klima der elevene er språklig rustet til å tre inn i den relasjonelle verden en samtale om en litterær tekst er.

\section{Relasjoner i laringssituasjonen}

Dette bringer oss til hvordan Biesta omtaler relasjonen mellom lærer og elev. Til det bruker han de tre begrepene «tillit» (trust), «ubehag» (violence) og «ansvar» (responsibility). Eleven må ha tillit til læreren og det læringsinnholdet læreren presenterer. Idet du engasjerer deg i en læringssituasjon, risikerer du å lære mer enn det du ønsker eller hadde forestilt deg at du skal lære. Du kan lære noe helt annet enn det du først hadde tenkt, og du kan samtidig lære om deg selv og dine reaksjoner. I noen tilfeller vil læringsprosessen og det du lærer endre hvem du er og hvordan du ser på verden (Biesta, 2006). En slik prosess er ifølge Biesta bare mulig hvis eleven har tillit til læreren. For eleven kan hele denne prosessen ses på som en risiko. Biesta kaller dette forholdet «trust without ground» (2006, s. 25) fordi eleven må våge å kaste seg ut $\mathrm{i}$ læringssituasjonen uten sikkerhetsnett. Hvis du som elev reserverer deg, tar forholdsregler eller kalkulerer risikoen i forkant, vil du ifølge Biesta ta vekk en grunnleggende dimensjon ved det å utdanne deg. I den aktuelle litteratursamtalen jeg viser til, vil det være flere innslag av tillit. Først og fremst må elevene ha tillit til fortellingen, de må tro på den og ikke avvise den. Å lese en skjønnlitterær tekst innebærer også å godta den fiksjonsverdenen forfatteren presenterer. Videre må elevene ha tillit til læreren for å våge å ytre sine meninger om teksten. En vet ikke hvordan ens egne innspill blir mottatt, en kan ikke annet enn å stole på læreren, egen forståelse av teksten og egne medelever. Først da kan de bli en del av det fellesskapet en litteratursamtale er. 


\section{Gro Ulland}

Den neste komponenten en læringsprosess innebærer, er det Biesta kaller (transcendental) violence (2006, s. 26). En presis oversettelse av «violence» i denne sammenhengen, vil være «ubehag» ${ }^{2}$. Elevene må konfronteres med et læringsinnhold, og respondere på dette, gjerne i form av å svare på lærerens (mulig) ubehagelige spørsmål. En litteratursamtale kan fremkalle flere aspekter av ubehag. For det første kan selve teksten - innholdet - være ubehagelig. Den konkrete fortellingen om Brune byr for eksempel på voksne som ikke bryr seg, ensomhet, det å bli truet av større barn og ubehaget ved å gå ut i mørket om natten. Videre vil lærerens spørsmål eller medelevers innspill i en litteratursamtale kunne medføre ubehag. Det er ubehagelig når det en trodde stemte, ikke stemmer likevel eller når holdninger en trodde en hadde, viser seg å ikke være anvendbare eller oppriktige nok. Til sist er det ubehagelig å skulle ytre egne meninger og tolkninger i samspill med andre. Lærerens spørsmålstilling er avgjørende for at en elev kan ytre sin egen stemme. Biesta understreker at spørsmål som «What do you think about it?» og «Where do you stand» (2006, s. 28) er svært vanskelige spørsmål, men samtidig er det spørsmål som utfordrer og dermed kan forme elevene. I en litteratursamtale er det de autentiske spørsmålene som anses som utviklende (Dysthe, 1995). Autentiske spørsmål forstås som reelle spørsmål en stiller fordi en ikke nødvendigvis vet svaret på dem. Dette i kontrast til lukkede spørsmål eller kontrollspørsmål som kun gir eleven anledning til å vise at han husker hva han har lest eller samtalt om. Det er de autentiske spørsmålene som samsvarer med Biestas utdannende spørsmål, og det er disse som kan stå for vekst både hos individet og for tekstsamtalen som helhet.

Den tredje komponenten Biesta (2006) skisserer, er lærerens store ansvar, først og fremst for elevens subjektivitet, det unike i hver elev, men også for at læringsmøtene skal være kvalitative møter. Biesta sier om lærerrollen at «as educators we are always interfering in the lives of our students and (...) this interference can have a deep, transforming, and even disturbing impact on our students» (2006, s. 29). Både Biesta og Klafki understreker lærerens ansvar i undervisningssituasjonen. Klafki først og fremst i utvelgelse og forberedelse av innhold, Biesta hovedsakelig i å gi rom for elevene i den gitte undervisningssituasjonen. Slik jeg ser det, avhenger de to ulike variantene av ansvar av hverandre. Hvis læreren har valgt et emne som har en substans som kan være av verdi for elevene, er det ikke noe i veien for å undervise på en måte som inviterer til respons. På samme måte utelukker ikke en responsgenererende undervisning at læreren først må vurdere hva i et innhold som kan peke utover og gi betydning.

\section{Litteratursamtalen i lys av Biestas forestilling om respons}

I eksemplene vi skal se nærmere på, leser læreren høyt et kapittel i boka Brune (2013) for klassen, før han inviterer til en samtale om det de akkurat har lest. I tekstutdraget

\footnotetext{
${ }^{2}$ En direkte oversettelse av «violence» vil være vold. Det er imidlertid følelsen av det brutale ved å møte ny kunnskap og nye forestillinger Biesta beskriver, og en slik beskrivelse dekkes best av det norske ordet «ubehag» (http://www.nob-ordbok.uio.no/perl/ordbok.cgi?OPP=ubehag\&ant_bokmaal= 5\&ant_nynorsk $=5 \&$ bokmaal $=+\&$ ordbok $=$ bokmaal).
} 
vi går inn i har Rune bygget en hytte sammen med vennene sine. Da han går forbi hytta, oppdager han at Anton, prestesønnen og Ruben fra Drammen har overtatt hytten. De sparker i plankene og rugger i treverket. Syklene deres ligger like ved. Rune roper at de ikke skal ødelegge hytta:

- Ikke ødelegg hytta, gjentok Rune. -Den er vår.

- Står navnet ditt på den? sa Prestesønnen.

- Nei, men den er vår.

- Det er vår hytte nå, sa Anton. Han lo mens han sa det. - Vi trenger plankene.

Rune så på syklene og tilbake på guttene der oppe på bakken.

- Står navnet deres på syklene? sa han.

Guttene ble stille. Rune kjente at hendene skalv, men knyttet dem hardt sånn at guttene ikke skulle se det.

- Jeg trenger en slik sykkel, og hvis dere ikke har navn på dem, så tar jeg en med meg.

Han begynte å dra i den ene sykkelen. Guttene kastet fra seg plankene og begynte å løpe ned mot Rune.

(Øvreås, 2013, s. 23-25)

Umiddelbart etter tekstlesingen, samtaler lærer og elever om teksten:

Lærer: Hva synes dere om det som skjedde der?

Ivar: De var jo veldig slemme, og ødela hytten, og det som skjedde var at de sa de kunne ta den fordi navnet ikke sto på den, og da...

Mari: Han tenkte at han kunne giøre akkurat det samme med syklene. Bare at da lokket han de bort til seg og så løp han fra bank.

Jonas: Ingen av dem var jo snille, men de gikk jo på en måte i sin egen felle. Siden de sa jo «står det navn på det».

Julianne: Men han synes jo ikke det var noe gøy når de gjorde det med trehytten, så det var jo litt dumt at han gjorde det samme, men likevel så fortjente de det litt siden de hadde gjort det samme mot ham.

Lærer: Hadde han noe valg, egentlig?

Ivar: Ja, han kunne ha gått, og sagt det til moren.

Mari: $\quad$ Eller sagt det til presten.

Ivar: Ja, sagt det til presten at «sønnen din ødelegger min trehytte!»

Lærer: Er det sånn at hvis ikke det står navnet på noe, så kan en ta det?

Mari: Nei, det står ikke navnet på pulten min, men det er liksom mitt sted.

Jonas: Det står ikke navn på Julianne sitt pennal, men det er hennes. Det står ikke navn på læreren vår, det står ikke navn på håret mitt, det står ikke navn på skoene mine.

Julianne: Hvis du har kjøpt det, så er det ditt.

Denne litteratursamtalen gir elevene mulighet til å vise hvem de er og hva de står for idet de deltar i samtalen. Elevene viser tillit ved at samtlige tar ordet flere ganger. Ivar starter med å oppsummere handlingen, noe som kan ses på som en trygg start. Dette baner vei for at Mari kan utdype handlingen. Jonas er den første som vurderer handlingen, og dermed våger å vise seg selv og sitt verdisyn. Dette blir igjen 


\section{Gro Ulland}

fulgt opp av Julianne som støtter Jonas' syn, og samtidig vurderer hendelsen i boka ytterligere. Vi kan si at de blir en del av verden med sin deltakelse, noe som samsvarer med Biestas tanke om at en blir en del av verden gjennom å respondere $\mathrm{i}$ en læringsprosess.

Læreren har hele tiden et stort ansvar, både for at alle skal få delta med egne innspill, men også ved å stille spørsmål som kan få elevene til å tenke over teksten, seg selv og livet. Tekstens overføring til eget liv er kort, og overføringsspørsmål som «Er det sånn at hvis ikke det står navnet på noe, så kan en ta det?» vender elevene mot egen livssituasjon. Biesta skriver at å ta stilling til innholdet eller lærerens spørsmål, i mange tilfeller vil oppleves som ubehagelig, og den etiske utfordringen er tydelig i eksemplet over. Elevene blir utfordret når læreren spør om en kan ta det som ikke står noens navn på, og de prøver å finne plausible forklaringer på dette; «det er ditt hvis du har kjøpt det», og noe kan være ditt selv om du ikke har navnet ditt på det, er to konklusjoner. Videre må elevene vurdere om det er i orden å gjøre gjengjeld hvis noen har gjort en urett. Innspill som kommer frem er at «ingen av dem var jo snille», og at de slemme gikk i sin egen felle. De slemme fortjente det litt, men Rune kunne også valgt å si fra til noen voksne i stedet for å være like slem tilbake. Her berører samtalen etiske betraktninger som er aktuelle for 5. klassinger, og de må uttrykke egne holdninger om forhold det er sannsynlig at de selv kan komme til å oppleve.

Mens det første eksemplet kan gi grobunn for etisk refleksjon og danning, gir det neste eksemplet elevene en utfordring når det gjelder å tolke hva som skjer i fortellingen. Her er det elevenes tekst- eller litteraturforståelse som blir satt på prøve. Utdraget viser oss Rune som om natten kler seg ut som Brune og møter den døde bestefaren sin i skogen:

- Bestefar? Er det deg?

- Ja visst er det meg. Jeg sitter bare her og nyter den deilige sommernatta.

- Men ... er ikke du død?

- Jo visst, sa bestefar.

- Hvordan kan du sitte her da?

- Se på deg selv, sa Bestefar. - Ligger ikke du og sover?

- Eh ... jo, sa Brune nølende. Men det er Rune som ligger og sover. Jeg er Brune.

(...)

- I så fall er det Bestefar som er død, og jeg er Brunefar.

(Øvreås, 2013, s. 40-42)

Den litterære samtalen som følger, lyder:

Lærer: Det var en gammel mann. Hvem tror dere at det er?

To elever i kor: Bestefaren.

Lærer: Hvordan det?

Ivar: $\quad$ Det kan være at han ikke døde. Kanskje han bare var blitt bortført.

Mari: $\quad$ Kanskje han ikke følte seg velkommen i familien, så latet han som om han døde, så var det begravelse, og så gravde han seg opp igjen. Eller noen var med på å grave han opp igjen. 
Jonas: $\quad$ Ellers så var det bare noen andre han var i begravelse til.

Lærer: At de har tatt feil?

Mari: $\quad$ Det går ikke an med morfaren.

Jonas: Jo, fordi han drømte.

Mari: Ja, han drømte jo.

Ivar: $\quad$ Men kanskje han ikke drømte.

Mari: $\quad$ Men hvis han ikke drømte, så må jo ...

Julianne: $\quad$ Han spurte jo om farfaren var død, og så svarte farfaren ja. Han var død egentlig.

Mari: $\quad$ Kanskje dette er den andre bestefaren.

Tekstinnholdet utfordrer elevene fordi (B)Rune møter den døde bestefaren sin i skogen. Dette gir en usikkerhet eller et ubehag fordi elevenes erfaringshorisont har lært dem at en ikke kan se igjen mennesker som er døde. Læreren stiller spørsmål som krever at elevene tar stilling, ved å spørre hvordan den gamle mannen kan være bestefaren. Samtidig må elevene forholde seg til hverandres innspill; idet Jonas antyder at Brune drømmer, så endrer Mari sitt innspill fra at tekstens innhold er umulig, til at det kan være en drøm. Biesta skriver «We might look at learning as a response to what is other and different, to what challenges, irritates, or even disturbs us (rather than an acquisition of something we want to possess)» (2006, s. 27). Det vi ser her, er elevenes reaksjon på en forstyrrelse. At bestefaren viser seg er et uromoment, og elevenes innspill kan alle ses på som ledd i et forsøk på å reorganisere ubehaget uromomentet tilfører. Selv om tekstinnholdet vekker en uro eller et ubehag hos elevene, så har de full tillit til teksten. De avviser den ikke som usaklig, men bruker krefter på å få den til å stemme med egen fantasi og egne erfaringer. Det er et mysterium for dem hvordan Brune kan møte sin døde bestefar, og de lanserer idéer som at han har vært bortført, gravd seg selv opp igjen, eller at det hele er en drøm. Som Etienne Wenger (1998) påpeker, er samtalen et forhandlingsspill, der de mest plausible forklaringene vinner frem. Julianne har en sterk stemme når hun med støtte i teksten hevder at han «var død egentlig».

Disse to samtaleutdragene er verdifulle på hver sine vis. Det første viser hvordan tekst og samtale kan øve opp den etiske dømmekraften til elevene, mens det andre viser hvordan tekstens kvalitet øver opp elevenes estetiske dømmekraft. I det første eksempelet ser vi hvordan teksten er ilagt både verdier og holdninger som berører elevenes egne holdninger. En samtale om hvem som eier hytta og syklene kan utvikle elevene som mennesker og samfunnsborgere. Situasjonen teksten beskriver vekker ubehag fordi elevene blir utfordret til å mene noe om hva som er rett og galt, og samtidig kan det være grufullt å utlevere seg selv og egne meninger. I det andre samtaleutdraget grunner elevene over hvordan det kan ha seg at Brune kan møte den døde bestefaren, og dette bruddet med det de har forventet vekker et ubehag fundert på forvirring fordi teksthandlingen vanskelig lar seg forklare rasjonelt. Hvis lesing skal føre til estetisk danning, innebærer det at en også må lese tekster en ikke umiddelbart forstår (Aase, 2005b). Tekstutdraget elevene leser bryter med elevenes realistiske forventningshorisont, og gir elevene en erfaring i hva fiksjon kan være. Teksten og samtalen øver elevene i å godta fiksjonskonvensjonen, og synliggjør 


\section{Gro Ulland}

samtidig at en trenger sjangerkunnskap for å forklare det fantastiske i fortellingen. Slik øver både tekst og samtale elevene i estetisk, litterær danning.

Selv i sin usikkerhet har elevene også tillit til situasjonen, til at de blir hørt og tatt på alvor. Dette er også lærerens ansvar og rolle i en litteratursamtale, der han skal ivareta alles innspill, skape en opplevelse av fellesskap, men samtidig gi elevene noe å bryne seg på (Hennig, 2010). I eksemplene over lar læreren elevene reflektere over hverandres innspill, men han bidrar også med oppklarende spørsmål og verdsetting av enkeltelever ved å sikre at deres utsagn kommer klart frem. Læreren skal gi elevene muligheten til å få en stemme (Biesta, 2006), og ved å ha en veiledende, spørrende, men inkluderende holdning, legger han til rette for nettopp det. Både valg av innhold og spørsmålsstilling gjør det mulig for elevene å ha en stemme i samtalen. I eksempelet over kan vi spore en deltakelse der det virker betydningsfullt for elevene å bidra med egne innspill og å respondere på andres innspill. Resultatet kan være at de samtidig lærer noe om seg selv og egne reaksjoner, og noen ganger kan dette utvide hvordan de ser på verden (Biesta, 2006).

\section{Har litteratursamtalen danningspotensial?}

Å svare på om litteratursamtalen har danningspotensial fordrer egentlig to innganger til spørsmålet; 1) har teksten en baserer samtalen på danningspotensial, og 2) har selve samtalen danningspotensial. Her har vi både med innhold og prosess å gjøre, både tekst og samtale. Leif Johan Larsen refererer til Paul Ricoeur for å forklare hva det er elevene møter i en litterær tekst:

I romanen kan vi få direkte tilgang til personenes indre, og dette kan virke inn på vår oppfatning av de personene vi møter i den virkelige verden - inkludert oss selv - for gjennom romanen lærer vi å fortolke både oss selv og andre personer. (...) Ved å gå omveien om «den annen» - slik han fremstilles i litteraturen - kan man forstå seg selv og den verden man lever i. Dermed kan også litteraturen bevirke endret sosial praksis. (...) Under lesningen av fiksjonsfortellinger feller leseren kontinuerlig verdidommer over personer og handlinger, og utforsker det gode og det onde. (Ricoeur (1992), gjengitt i Larsen, 2005, s. 102-103).

Med dette i minne kan vi forstå det slik at litteraturlesingen åpner opp for dannelse ved å øve opp den estetiske og etiske dømmekraften. Klafki understreker hvordan det dannende må peke fremover og ha betydning for elevens videre liv: «Everything which claims to be content of education must also have a significance for the future of those to be educated» (2000, s. 149). Hvis en ser for seg eleven som en mottaker av kulturelle overleveringer, så vil han gjennom samtaledeltakelse også være en aktiv viderefører og fornyer av denne kulturen. Larsen viser igjen til Ricoeur når han hevder at fiksjonen kan anvendes på livet, ved at leseren identifiserer seg med karakterene og finner modeller for hvordan de kan organisere egne liv (Larsen, 2005). Litteraturlesingen kan også forespeile oss våre mulige fremtidige livshistorier, og også dette gir gjenklang i Klafkis kriterium om betydning for elevenes videre liv.

$\AA$ lese en tekst innebærer å hengi seg selv. Her kan vi trekke inn Biestas begrep om «tillit» (Biesta, 2006). For at litteraturen skal kunne ha en innvirkning på eleven, 
må han tro på teksten og det litterære universet teksten tilbyr. Han kan ikke avvise innholdet, og han kan heller ikke kalkulere hvilke tanker og reaksjoner innholdet vil generere. På samme måte som Biesta beskriver at lærerrollen kan ha en dyp, omdannende og til og med forstyrrende virkning på elevenes liv (2006, s. 29), kan også tekstinnhold tvinge frem omdannende virkninger og endringer. Eksemplene i denne artikkelen viser at selve teksten kan ha potensial til å utvikle elevene både på det etiske og det estetiske nivået. Forfatterens valg av tematikk utvikler elevenes etiske forståelse, mens bruk av fantastikk som virkemiddel utvikler elevenes estetiske, litterære forståelse.

Så til selve samtalen. Det elevene får ut av litteraturlesingen kan ikke måles, men elevene kan artikulere sin forståelse i en samtale om litteraturen. I dette ligger et utviklingsmoment eller et danningspotensiale; fordi samtalen tvinger oss til å stoppe opp og se tilbake på lesingen og fordi vi blir tvunget til å møte andre lesinger enn vår egen (Aase, 2005a). Biesta (2006) beskriver en læringssituasjon som en praksis som tillater individuell respons og deltakelse. En litteratursamtale kan være en arena som sammenfaller med denne beskrivelsen, fordi den inviterer til reaksjon på et innhold, både i form av et tekstinnhold og medelevers tanker om denne teksten. Begge deler gir en anledning til å møte noe en ikke kjente fra før og kanskje også noe som ikke stemmer med tidligere antagelser. Biesta er opptatt av at en skal hevde sin egen stemme i læringssituasjonen, bak dette ligger både å ha forstått noe, og å bryne det en har forstått mot andres innspill, dernest innebærer det å våge å ytre dette i læringssituasjonen. Argumentativ kommunikasjon med andre i et offentlig språk kan være identitetsutviklende og dannende, i og med at det også oppøver våre kommunikative og sosiale ferdigheter.

Tekstlesingen og samtalene som er eksemplifisert her kan føre til at elevene tenker over eget liv, over hva som er mulig og ikke mulig, over egne grenser for virkelighet og fantasi, om sitt eget forhold til sine besteforeldre eller over hva som gjør at noe er ditt og noe er mitt. Samtalen kan også giøre noe med elevens tanker om egen deltakelse, om å våge å ta ordet, om å få respons på egne utsagn, og om å lytte til det andre har sagt. Det er først og fremst læreren som lager rammene for litteratursamtalen. Ved å bygge innspill på elevenes respons, kan elevene føle seg verdifulle, noe som i neste omgang kan øke den enkeltes deltakelse. At ulike stemmer møtes i litteratursamtalen kan føre til at eleven dannes, utvikles og når lenger i sine tanker enn han ville ha giort før dette møtet fant sted.

\section{Biografi}

Gro Ulland er ansatt som høgskolelektor ved avdeling for lærerutdanning, Høgskolen i Bergen, der hun underviser i lese- og skrivekunnskap og forsker på litteratursamtalen og barns ordforståelse. Hun er hovedforfatter bak norskverket Ordriket 1-7 (Fagbokforlaget) og har skrevet flere kapitler om litteraturarbeid og barns lesing i Norskboka 1 og 2 (Universitetsforlaget).

\section{Referanser}

Biesta, G.J.J. (2006). Beyond Learning. Democratic Education for a Human Future. London: Paradigm Publishers. 


\section{Gro Ulland}

Dewey, J. (1990/1902). The School and Society and The Child and the Curriculum. Chicago: University of Chicago Press.

Dysthe, O. (1995). Det flerstemmige klasserommet. Skriving og samtale for å lare. Oslo: Gyldendal.

Hennig, Å. (2010). Littercer forståelse. Innføring i litteraturdidaktikk. Oslo: Gyldendal.

Hopmann, S.T. (2010). Undervisningens avgrensning: Didaktikkens kjerne. I J.H. Midtsundstad \& I. Willbergh (Red.), Didaktikk. Nye teoretiske perspektiver på undervisning (s. 19-43). Oslo: Cappelen Damm.

Klafki, W. (2000). Didaktik Analysis as the Core of Preparation of Instruction. I I. Westbury, S. Hopmann \& K. Riquarts (Red.), Teaching as a reflective practice. The German didaktik tradition (s. 139-159). New Jersey: Lawrence Earlbaum Associates.

Larsen, L.J. (2005). Identitet, dannelse og kommunikasjon. I B. Kvalsvik Nicolaysen \& L. Aase (Red.), Kulturmøte $i$ tekstar. Litteraturdidaktiske perspektiv (s. 88-105). Oslo: Det norske Samlaget.

Wenger, E. (1998). Communities of practise Learning, Meaning and Identity. Cambridge: Cambridge University Press.

Willbergh, I. (2010). Mimetisk didaktikk: Om undervisning som kunst. I J.H. Midtsundstad \& I. Willbergh (Red.), Didaktikk. Nye teoretiske perspektiver på undervisning (s. 46-62). Oslo: Cappelen Damm.

Aase, L. (2005a). Litterære samtalar. I B. Kvalsvik Nicolaysen \& L. Aase (red.), Kulturmøte i tekstar. Litteraturdidaktiske perspektiv (s. 106-124). Oslo: Det norske Samlaget.

Aase, L. (2005b). Norskfagets danningspotensial i fortid og samtid. I A.J. Aasen \& S. Nome (Red.), Det nye norskfaget (s. 35-47). Bergen: Fagbokforlaget.

Øvreås, H. \& Torseter, Ø. (2013). Brune. Oslo: Gyldendal. 